\title{
PENINGKATAN SARANA DAN PENGETAHUAN UNTUK MENDUKUNG PENERAPAN E-RAPOR DAN UKS DI MIM POTRONAYAN 1
}

\author{
${ }^{1}$ Heru Supriyono, ${ }^{2}$ Nur Muhammad Akbar Isnen, \\ dan ${ }^{3}$ Dendy Murdiyanto \\ ${ }^{1}$ Program Studi Teknik Elektro, Fakultas Teknik, Universitas Muhammadiyah Surakarta \\ ${ }^{2}$ Program Studi Informatika, Fakultas Komunikasi dan Informatika, Universitas Muhammadiyah Surakarta \\ ${ }^{3}$ Program Studi Kedokteran Gigi, Fakultas Kedokteran Gigi, Universitas Muhammadiyah Surakarta \\ Email : ${ }^{1}$ Heru.Supriyono@ums.ac.id
}

\begin{abstract}
ABSTRAK
Mitra dari kegiatan pengabdian Program Kemitraan Masyarakat (PKM) ini adalah Madrasah Ibtidaiyah Muhammadiyah (MIM) Potronayan 1. Permasalahan utama yang diangkat dalam kegiatan ini ada dua yaitu sekolah belum dapat menerapkan e-rapor atau yang dikenal dengan istilah aplikasi rapor digital (ARD) dan permasalahan belum optimalnya peran usaha kesehatan sekolah (UKS) terutama usaha kesehatan gigi sekolah (UKGS). Tujuan dari kegiatan ini adalah untuk meningkatkan sarana pendukung untuk penerapan e-rapor dan meningkatkan pengetahuan guru dan siswa untuk mendukung UKS dan UKGS. Metode pelaksanaan kegiatan yang utama adalah dengan menerapkan infrastruktur komputer untuk mendukung penerapan e-rapor dan pelaksanaan pelatihan dan penerapan aplikasi Android untuk meningkatkan pengetahuan tentang pemeliharaan kesehatan gigi dan mulut serta UKS. Hasil yang diperoleh dari kegiatan ini adalah mitra sudah mempunyai sarana infrastruktur komputer yang sesuai dengan kebutuhan untuk penerapan e-rapor dan guru dan siswa sudah mendapatkan pelatihan dan aplikasi Android untuk meningkatkan pengetahuan pemeliharan gigi dan mulut. Evaluasi dilakukan dengan wawancara dan observasi langsung serta menggunakan kuesioner. Hasil wawancara dan observasi menunjukkan bahwa infrastruktur komputer yang diterapkan sudah sesuai dengan kebutuhan mitra. Hasil analisis kuesioner menunjukkan 90\% peserta pelatihan program aplikasi Android media pembelajaran kesehatan gigi dan mulut mempunyai tampilan yang menarik, mudah digunakan, mempunyai konten yang mencukupi dan sudah layak digunakan untuk sarana pembelajaran. Selain itu 100\% peserta merasa puas dengan pelaksanaan kegiatan. Dampak dari aplikasi Android media pembelajaran kesehatan gigi dan mulut yang diterapkan adalah meningkatkan suasana belajar yaitu membuat belajar kesehatan gigi dan mulut lebih menyenangkan jika dibandingkan hanya dengan menggunakan material cetakan dan juga meningkatkan pengetahuan peserta dalam pengelolaan kesehatan gigi dan mulut.
\end{abstract}

Kata kunci: aplikasi rapor digital, aplikasi Android, e-rapor, pemeliharaan kesehatan gigi.

\section{ABSTRACT}

The partner of this community services, Community Partnership Program/Program Kemitraan Masyarakat (PKM) are Madrsah Ibtidaiyah Muhammadiyah (MIM) Potronayan 1. The main problems raised in this activity are two, i.e. schools have not been able to implement electronics academic report/e- 
rapor or known as digital report cards application/ Aplikasi Rapor Digital (ARD) and role of the school health facility/ Usaha Kesehatan Sekolah (UKS), especially the school dental health business (UKGS) is not optimal yet. The purpose of this activity is to improve the supporting facilities for implementing e-report cards and increase the knowledge of teachers and students to support UKS and UKGS. The main implementation method of the PKM are involving the application of computer infrastructure to support the application of e-report cards and the training programme for teacher and student using Android applications to increase knowledge about maintaining dental and oral health and UKS. Evaluation is done by interview and direct observation and using a questionnaire. The results of interviews and observations showed that the computer infrastructure that was implemented has fulfilled the partners' requirement. The results of the questionnaire analysis showed that $90 \%$ of participants satisfy that the Android application program for dental and oral health learning media had an attractive appearance, were easy to use, had sufficient content and were already suitable to use as learning tools. In addition, $100 \%$ of the participants were satisfied with the implementation of the activity. The impact of the Android application of dental and oral health learning media applied is able to improve the learning atmosphere, makes learning more enjoyable when compared only by using printed materials and also increasing the participants' knowledge in managing dental and oral health.

Keywords: aplikasi rapot digital, aplikasi Android, e-rapor, pemeliharaan kesehatan gigi.

\section{PENDAHULUAN}

Kecamatan Nogosari adalah salah satu kecamatan dalam wilayah Kabupaten Boyolali Propinsi Jawa Tengah. Kawasan kecamatan ini letaknya membentang disebelah utara Bandara Internasional Adisumarmo. Mitra kegiatan pengabdian ini adalah Madrasah Ibtidaiyah Muhammadiyah (MIM) Potronayan 1 yang terletak di Dukuh Potronayan Desa Potronayan Kecamatan Nogosari Kabupaten Boyolali. Lokasi geografis desa Potronayan adalah kirakira 2 kilometer disebelah utara Bandara Internasional Adisumarmo. MIM Potronayan 1 sudah mempunyai fasilitas gedung lokasi kelas milik sendiri dengan fasilitasnya terdiri dari 8 ruang kelas, ruang guru, ruang kepala sekolah, perpustakaan, dan halaman bemain. Walaupun fasilitas fisik terbilang standar namun dengan semangat yang kuat dan manajemen sekolah yang baik maka sekolah ini dapat memperoleh akreditasi A.

Jumlah siswa yang terdaftar total adalah 152 anak. Walaupun jumlah siswanya tidak begitu banyak sekolah ini mempunyai potensi yang cukup membanggakan ditingkat kabupaten sebagai contoh pada tahun 2013 siswa sekolah ini menjadi juara 2 dan 3 dalam lomba olimpiade Matematika dan Bahasa untuk sekolah dalam yayasan Muhammadiyah tingkat kabupaten
Boyolali yang diadakan oleh Jaringan sekolah Muhammadiyah (JSM). Selain itu, dari tahun ketahun tingkat kelulusan selalu lulus $100 \%$. Mitra memiliki 11 orang guru yang terdiri dari 4 guru laki-laki dan 7 guru perempuan dengan pendidikan strata 1 (sarjana).

Permasalahan umum yang dihadapi oleh mitra adalah persaingan dengan sekolah sekitar dalam mendapatkan siswa baru. Bagi sekolah swasta, keberadaan peserta didik baru akan sangat menentukan keberlanjutan beroperasinya sekolah. Kemampuan sekolah dalam menarik siswa baru sangat tergantung dari saya saing mitra dibandingkan dengan sekolah lain diantaranya dari aspek fasilitas pendidikan yang disediakan, besarnya biaya pendidikan yang ditetapkan, proses pendidikan, standar kompetensi lulusan yang direncanakan, dan prestasi yang dicapai sekolah.

Dari permasalahan umum yang diuraikan dalam analisis situasi, dalam kegiatan pengabdian ini, tim pengusul dan mitra bersepakat untuk memilih permasalahan prioritas untuk diangkat dalam kegiatan PKM yaitu masih belum optimalnya pelayanan administrasi akademik dan usaha kesehatan sekolah. Permasalahan ini disepakati dipilih karena permasalahan ini sangat penting dan cukup urgen dan juga dengan mempertimbangkan bahwa permasalahan

Warta LPM, Vol. 22, No. 2, September 2019 
yang dipilih tidak terlalu kompleks dan tidak membutuhkan waktu dan biaya yang besar sehingga ini adalah pilihan yang rasional.

Salah satu faktor pendukung daya saing sekolah adalah kualitas pelayanan administrasi akademik. Kondisi saat ini adalah guru mengolah rapor dengan menggunakan program spreadsheet seperti Microsoft Excel. Walaupun sudah menggunakan komputer namun proses pengolahan rapor ini tetap disebut manual karena guru harus mengolah nilai satu demi satu siswa. Guru banyak mengalami kerepotan dalam mengolah rapor secara manual yang disebabkan oleh besarnya usaha yang dan banyaknya waktu yang diperlukan dalam mengolah nilai agar dapat selesai pada waktu yang dijadwalkan untuk dibagikan kepada siswa. Teknologi informasi berbasis komputer dapat dimanfaatkan untuk membantu mengatasi permasalahan ini yaitu dengan menerapkan sistem pengolahan raport berbasis komputer untuk meringankan usaha yang harus dikeluarkan guru dan mempersingkat waktu yang dialokasikan dalam pengolahan rapor. Data rapor juga akan dapat tersimpan dalam basisdata dalam komputer sehingga dapat digunakan pada waktu yang akan datang apabila diperlukan.

Berdasarkan wawancara dengan kepala sekolah, guru dan karyawan (operator komputer) dan observasi secara langsung dapat diketahui bahwa untuk sekolah tingkat madrasah ibtidaiyah, pemerintah melalui kementrian sudah mulai menggunkan sistem rapor elektronik berbasis komputer yang dikenal dengan istilah Aplikasi Rapor Digital (ARD). Aplikasi ARD yang akan diterapkan bagi sekolah madrasah secara nasional mempunyai arsitektur terpusat yaitu ada sistem komputer dan basisdata terpusat secara nasional yang harus diakses oleh sekolah. Untuk dapat mengakses sistem ARD dan basisdata pusat maka sekolah harus mempunyai infrastruktur komputer yang terdiri dari server lokal sekolah dan jaringan lokalnya. Server lokal sekolah ini harus terhubung dengan sistem dan basisdata nasional melalui internet.

Letak geografis sekolah mitra adalah didaerah perdesaan yang cukup jauh dari pusat kota ditambah lagi dengan kontur kawasan yang tidak rata. Dengan kondisi geografis ini, sekolah mitra mengalami kesulitan untuk mendapatkan akses internet dari internet service provider
(ISP) secara langsung. Satu-satunya akses internet yang dapat digunakan adalah dengan memanfaatkan akses data internet dari seluler menggunakan jaringan Global Systems for Mobile Communication (GSM).

Mulai tahun pelajaran 2017/2018 mitra menerapkan jam pelajaran sehari penuh (fullday) yaitu siswa pulang jam 15.30. Jam pelajaran yang panjang ini sebaiknya harus didukung dengan layanan pendukung yaitu berupa fasilitas usaha kesehatan sekolah (UKS) sebagai pertolongan pertama untuk mengantisipasi adanya kecelakaan atau siswa sakit saat jam sekolah. Idealnya sebuah sekolah seharusnya mempunyai fasilitas UKS yang mencukupi baik dari segi prasarana ruangan UKS, sarana perlengkapannya, maupun guru atau karyawan yang mempunyai keahlian atau keterampilan dalam pemeliharaan kesehatan seperti perawat selama jam proses belajar mengajar. Kondisi saat ini mitra sudah memiliki fasilitas UKS walaupun masih terbatas. Permasalahan yang dihadapi mitra adalah belum optimalnya peran UKS yang tersedia terutama dalam hal pengetahuan dalam pemeliharaan kesehatan gigi dan mulut dan belum optimalnya kelengkapan peralatan UKS.

Berdasarkan hasil observasi, analisis situasi dan diskusi dengan kepala sekolah dan guru maka dapat dirumuskan dua permasalahan yang dihadapi mitra yang akan diselesaikan dalam kegiatan pengabdian. Permasalahan pertama adalah sekolah belum dapat menerapkan e-rapor/ ARD. Akar masalahnya adalah sekolah belum mempunyai infrastruktur komputer yang mencukupi. Permasalahan kedua adalah belum optimalnya UKS dimana akar masalahnya adalah masih terbatasnya sarana dan pengetahuan yang dimiliki oleh guru sebagai pembina UKS terutama mengenai pemeliharaan kesehatan gigi dan mulut.

Untuk membantu mengatasi permasalahan pertama yaitu sekolah mitra belum dapat menerapkan ARD, tim pelaksana mengusulkan solusi yaitu pengaplikasian infrastruktur komputer dengan memanfaatkan WLAN dan jaringan internet seluler GSM. Taget luaran utama pelaksanaan kegiatan ini adalah sekolah mitra sudah mempunyai infrastruktur komputer yang sesuai dengan kebutuhan sehingga bisa menerapkan e-rapor/ARD. Untuk permasalahan kedua, solusi yang ditawarkan oleh tim 
pelaksana meliputi pelatihan pengelolaan UKS dengan fokus pada kesehatan gigi dan mulut, dan penerapan media pembelajaran kesehatan gigi dan mulut berbasis aplikasi Android.

Jaringan komputer dapat digunakan untuk menyambungkan dua komputer atau lebih sehingga dapat saling berkomunikasi data meliputi saling mengirim dan menerima data. Secara umum jaringan komputer dibagi menjadi beberapa jenis yaitu: jaringan komputer yang bersifat lokal yaitu local area network (LAN), jaringan satu kota yaitu metropolitan area network (MAN) dan jaringan area luas yaitu wide area network (WAN). Jaringan LAN biasanya disusun dalam area terbatas sehingga tidak membutuhkan jaringan internet sedangkan jaringan MAN dan WAN karena mencakup area yang luas maka membutuhkan jaringan internet (Tanenbaum, 2003). Jaringan LAN dapat diimplementasikan dengan menggunakan media transmisi kabel Unshielded Twisted Pair (UTP) maupun dengan menggunakan media transmisi nirkabel yaitu dengan menggunakan gelombang elektromagnetik dengan frekuensi $2.4 \mathrm{GHz}$ atau yang dikenal dengan wireless LAN (WLAN). Jaringan lokal nirkabel WLAN yang banyak diimplementasikan menggunakan standar internasional IEEE 802.11 mempunyai keunggulan yaitu tidak perlu instalasi kabel sehingga mendukung fleksibilitas yaitu komputer client dapat bergerak kemana saja dalam jangkauan perangkat access point (Supriyono dkk, 2016).

Jaringan MAN dan WAN dapat dibuat dengan menggunakan jaringan internet sehingga dapat menghubungkan komputer di satu tempat dengan komputer ditempat lain yang jauh (Supriyono dkk, 2013). Menurut Tanenbaum (2003), infrastruktur media komunikasi data yang biasanya dipakai dalam pembuatan infrastruktur jaringan internet adalah kabel telepon, kabel serat optik, maupun dengan gelombang elektromagnetik yang semuanya memiliki keterbatasan akses terutama pada rentang wilayah, kontur geografi, dan ada tidaknya halangan atau hambatan. Kabel telepon membutuhkan biaya yang mahal dalam intalasi/ pemasangan dan hanya terjangkau diwilayah perkotaan dan sekitarnya saja. Selain itu, kabel telepon mempunyai keterbatasan bandwidth dalam pengiriman data. Kabel serat optik menawarkan kecepatan pengiriman data/ bandwidth yang tinggi namun harganya mahal dan juga mempunyai biaya instalasi yang mahal dengan area cakupan yang lebih terbatas dibandingkan kabel telepon yaitu biasanya pada daerah perkotaan. Akses internet juga bisa dilakukan dengan menggunakan gelombang elektromagnetik. Untuk jaringan MAN dan WAN, gelombang elektromagnetik dengan frekuensi ultra tinggi yaitu 10-66 GHz atau yang banyak dikenal dengan wireless broadband banyak digunakan. Gelombang elektromagnetik jenis ini membutuhkan garis hantar yang lurus dan langsung (line of sight) sehingga mempunyai kelemahan utama yaitu terpantulkan oleh penghalang sehingga kurang sesuai untuk diterapkan pada daerah dengan kondisi geografis yang tidak rata dan banyak pepohonan.

Gelombang elektromagnetik lainnya yang digunakan sebagai media pembawa data internet adalah gelombang elektromagnetik berbasis seluler GSM yang hingga saat ini yang paling banyak digunakan adalah generasi keempat atau yang dikenal sebagai 4G. Kelebihan dari media komunikasi data internet berbasis sinyal GSM adalah sangat mendukung mobilitas dan mempunyai jangkauan layanan sangat luas dengan baik untuk daerah perkotaan maupun perdesaan (Santoso dkk, 2015; Fauzi dkk, 2012).

Usaha Kesehatan Sekolah (UKS) adalah bagian dari program pemerintah yang bertujuan untuk menjaga dan meningkatkan keehatan di lingkungan sekolah (Kemenkes, 2017). Program kegiatan pada UKS biasanya meliputi edukasi untuk warga sekolah untuk menciptakan lingkungan yang sehat sampai dengan melakukan perawatan darurat sederhana apabila ada warga sekolah yang sakit misalnya terjadi kecelakaan saat aktivitas di sekolah atau sakit. Cakupan pemeliharaan kesehatan juga termasuk pemeliharaan kesehatan gig dan mulut.

Pelatihan atau kegiatan pembelajaran dapat digunakan sebagai usaha untuk meningkatkan pengetahuan dan keterampilan pada suatu bidang ilmu. Proses pembelajaran yang paling umum dijumpai adalah proses pembelajaran dengan metode pemaparan/ presentasi dan dengan menggunakan media pembelajaran berbasis cetakan seperti buku. Media pembelajaran berbasis elektronik seperti dengan aplikasi pada smartphone maupun pada

Warta LPM, Vol. 22, No. 2, September 2019 
komputer menawarkan berbagai kelebihan diantaranya adalah adanya visualiasi berupa gambar, suara, musik, atau juga dalam bentuk fitur tambahan seperti adanya game edukasi yang interaktif. Beberapa contoh penerapan media berbasis smartphone dan komputer untuk pembelajaran diantaranya adalah untuk pembelajaran aksara jawa dengan aplikasi berbasis desktop (Supriyono dkk, 2015), dan pembelajaran Aksara Jawa berbasis aplikasi Android (Supriyono dkk, 2016). Hasil publikasi tersebut menunjukkan bahwa media pembelajaran berbasis multimedia baik smartphone maupun komputer membuat proses pembelajaran lebih menarik jika dibandingkan dengan hanya menggunakan penjelasan/metode presentasi atau material cetakan lainnya.

Tujuan dari pelaksanaan kegiatan ini adalah untuk menyediakan infrastruktur sistem komputer guna mendukung penerapan e-rapor pada mitra dan untuk meningkatkan pemahaman guru dan siswa dalam pemeliharaan kesehatan gigi dan mulut sebagai bagian dari penyelenggaraan UKS.

Manfaat pertama yang diperoleh dari keberhasilan kegiatan ini adalah diperolehnya infrastruktur komputer sebagai sarana utama untuk penerapan e-rapor pada mitra sedangkan manfaat kedua adalah meningkatnya pemahaman guru dan siswa dalam pengelolaan gigi dan mulut.

\section{METODE PELAKSANAAN}

Kegiatan dilaksanakan selama enam bulan yaitu dari bulan Februari - Agustus 2019 bertempat di mitra kegiatan yaitu MIM Potronayan 1. Kegiatan pengabdian dilakukan dalam berbagai tahapan yang jadwalnya dapat dilihat pada Tabel 1.

Tahap pertama kegiatan pengabdian adalah sosialisasi kegiatan pengabdian kepada mitra yang dilaksanakan pada bulan Februari 2019. Pada tahap ini tim pelaksana berkoordinasi dengan mitra tentang rencana pelaksanaan meliputi rencana jadwal pelaksanaan, alat dan bahan yang diperlukan, peserta kegiatan, tempat dan sarana penunjang yang diperlukan, rencana susunan acara beserta penanggung jawabnya.
Tabel 1. Jadwal pelaksanaan kegiatan

\begin{tabular}{ll}
\hline \multicolumn{1}{c}{ Tahap } & Waktu Pelaksanaan \\
\hline Sosialisasi & Februari 2019 \\
\hline $\begin{array}{l}\text { Penyiapan alat dan } \\
\text { bahan }\end{array}$ & Februari-Juli 2019 \\
\hline $\begin{array}{l}\text { Instalasi infrastruktur } \\
\text { komputer dan pelatihan }\end{array}$ & Juli-Agustus 2019 \\
\hline $\begin{array}{l}\text { Evaluasi pelaksanaan } \\
\text { kegiatan }\end{array}$ & Agustus 2019 \\
\hline $\begin{array}{l}\text { Monitoring } \\
\text { keberlanjutan }\end{array}$ & $\begin{array}{l}\text { September- } \\
\text { November 2019 }\end{array}$ \\
\hline
\end{tabular}

Tahap kedua kegiatan pengabdian adalah penyiapan alat dan bahan yang diperlukan untuk pelaksanaan kegiatan. Tahap ini membutuhkan waktu sekitar 5 bulan dilaksakan pada bulan Maret-Juli 2019. Pada kegiatan ini, alat dan bahan yang diperlukan meliputi: (1) komputer PC yang akan difungsikan sebagai server dengan spesifikasi: Komputer PC:CPU(dengan spesifikasi : prosesor i-5 8400, RAM DDR4 8GB, Harddisk 3 TB), monitor LED 19 inchi, keyboard dan mouse, (2) komputer PC yang akan disungsikan sebagai client dengan spesifikasi: Komputer PC: CPU (dengan spesifikasi: prosesor i-5 2400, RAM DDR3 8GB, Harddisk 1TB), monitor LED 19 inchi, keyboard dan mouse, (3) Perangkat untuk akses internet dengan jaringan GSM: Mifi universal, (4) Perangkat PC untuk akses internet nirkabel: USB Wifi, (5) Printer tinta warna Cannon, (6) aplikasi media pembelajaran berbasis Android, (7) materi pelatihan tentang pengelolaan kesehatan gigi dan mulut, (8) smartphone dengan sistem operasi Android, (9) alat peraga untuk pelatihan pemeliharaan kesehatan gigi dan mulut, (10) kuesioner untuk evaluasi pelaksanaan kegiatan, (11) pengeras suara dan (12) LCD proyektor.

Tahap ketiga pelaksanaan kegiatan pengabdian adalah melakukan instalasi dan konfigurasi infrastruktur komputer dan melakukan pelatihan pemeliharaan gigi dan mulut. Sistem e-rapor yang akan diterapkan di MIM Potronayan 1 adalah e-rapor yang berbasis dalam jaringan (daring) dengan server terpusat yang dikelola oleh Kemenag. Untuk dapat mengakses program atau aplikasi e-rapor, untuk saat ini, sekolah mitra harus mempunyai komputer server lokal sekolah yang terhubung dengan basisdata pusat melalui jaringan internet. 


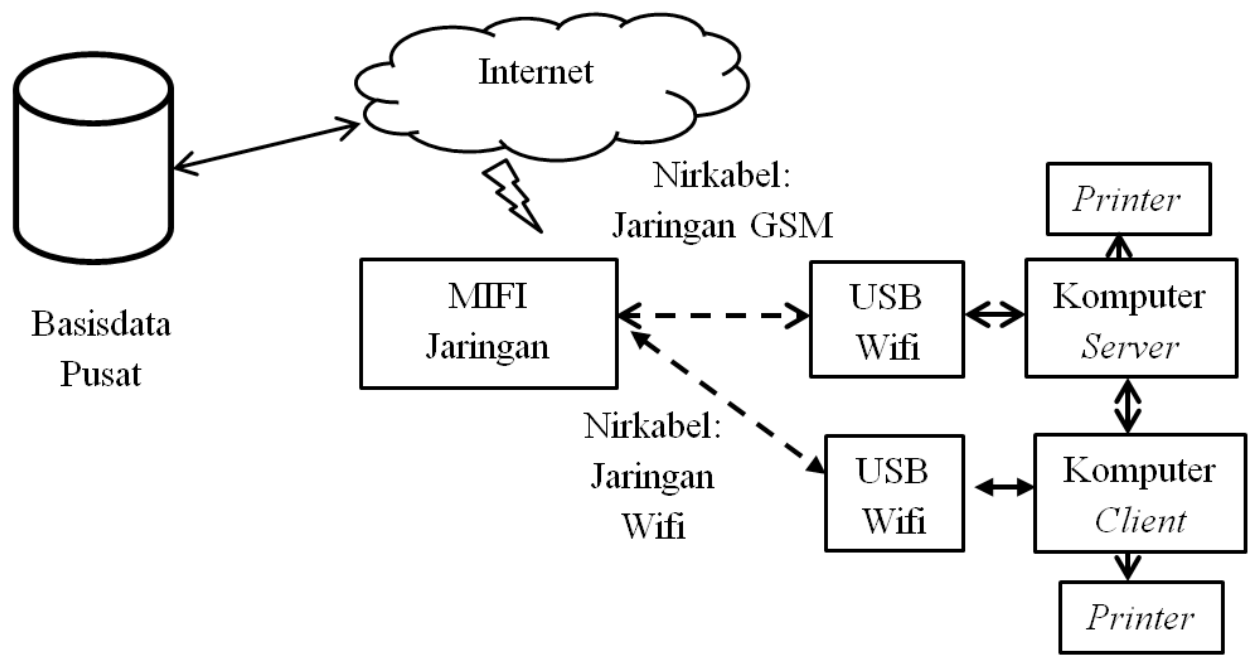

Gambar 1. Arsitektur sistem komputer untuk mendukung penerapan e-rapor di sekolah mitra.

komputer server (peladen) ini kemudian yang akan melayani komputer client yaitu komputer yang digunakan oleh guru untuk mengolah data nilai siswa. Lokasi sekolah mitra adalah didaerah perdesaan yang kurang terjangkau fasilitas akses internet dari penyedia internet/Internet Service Provider (ISP) baik melalui jaringan telepon kabel, serat optik maupun jaringan nirkabel. Satu-satunya akes internet yang cukup handal adalah akses internet melalui jaringan paket data GSM yang disediakan oleh operator telepon bergerak GSM. Oleh karena itu dalam kegiatan pengabdian ini jaringan internet berbasis paket data internet GSM digunakan untuk menghubungkan antara komputer server lokal sekolah dengan basisdata pusat. Komputer client kemudian dihubungkan dengan komputer server lokal sekolah dengan menggunakan jaringan lokal. Arsitektur infrastruktur komputer yang diimplementasikan pada sekolah mitra dapat dilihat pada Gambar 1.

Pelatihan pengelolaan kesehatan gigi dan mulut dilaksanakan pada tanggal 31 Agustus 2019 bertempat di MIM Potronayan 1. Pelatihan dibagi menjadi dua sesi yaitu pelatihan yang menggunakan metode penjelasan/presentasi dan pelatihan dalam hal penerapan media pembelajaran kesehatan gigi dan mulut menggunakan aplikasi Android.

Tahap ke empatadalah evaluasi pelaksanaan kegiatan. Pada tahap ini tim pelaksana kegiatan pengabdian mengadakan monitoring dan evaluasi kegiatan. Evaluasi kegiatan dilakukan dengan wawancara dengan kepala sekolah, guru dan operator sekolah tentang infrastruktur komputer yang sudah daplikasikan. Selanjutnya, untuk mengetahui efektifitas pelaksanaan pelatihan yang dilaksanakan, tim pelaksana akan menggunakan kuesioner.

Tahap terakhir pelaksanaan kegiatan adalah monitoring keberlanjutan. Setelah pelaksanaan PKM selesai, operator sekolah akan berperan sebagai pengelola infrastruktur komputer yang diaplikasikan dan guru yang sudah mengikuti pelatihan pemeliharaan gigi dan mulut akan menjadi nara sumber untuk penyelengaraan UKS khususnya dalam pemeliharaan kesehatan gigi dan mulut bagi siswa. Tim pelaksana masih akan melakukan pendampingan selama dua bulan.

\section{HASIL DAN PEMBAHASAN}

\section{Infrastruktur Komputer yang Diaplikasikan}

Infrastruktur komputer yang diaplikasikan dapat dilihat pada Gambar 2 dan Gambar 3. Komputer yang difungsikan sebagai server mempunyai spesifikasi teknis sebagaii berikut: CPU (dengan spesifikasi : prosesor i-5 8400, RAM DDR4 8GB, Harddisk 3 TB), monitor LED 19 inchi, keyboard dan mouse (Gambar 2) sedangkan komputer yang difungsikan sebagai client mempunyai spesifikasi CPU (dengan spesifikasi : prosesor i-5 2400, RAM DDR3 8GB, Harddisk 1TB), monitor LED 19 inchi, keyboard dan mouse (Gambar 3).

Warta LPM, Vol. 22, No. 2, September 2019 


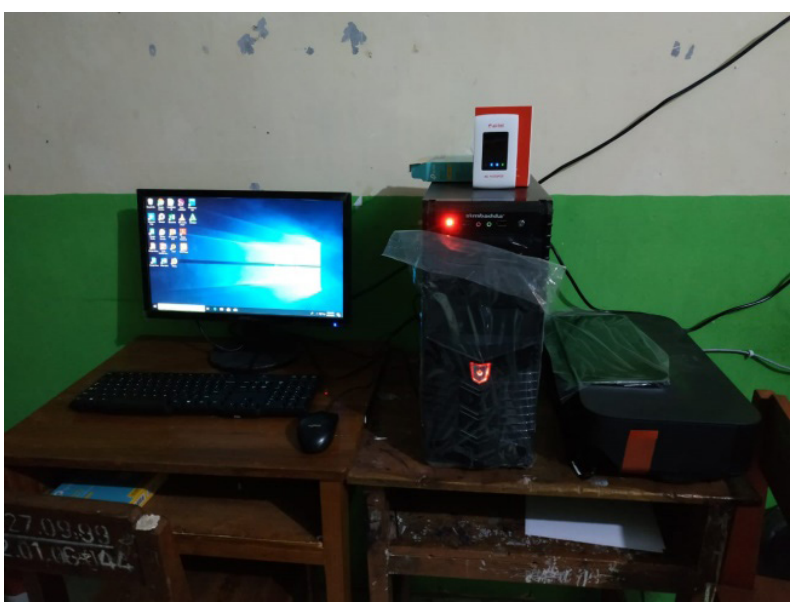

Gambar 2. Tampilan komputer yang digunakan sebagai server beserta perangkat mifi universal dan printer.

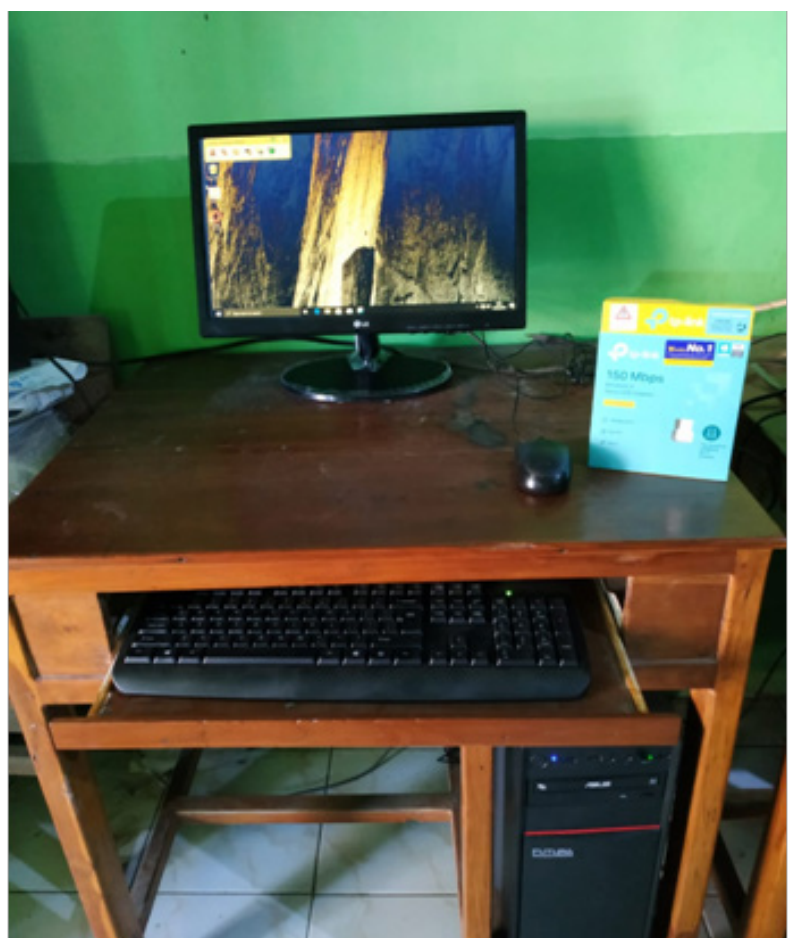

Gambar 3. Tampilan komputer yang diaplikasikan sebagai client.

Perangkat MIFI dengan jaringan GSM digunakan sebagai backbone (tulang punggung) komunikasi data internet yang menghubungkan antara komputer server lokal di sekolah dengan server pusat sehingga sekolah dapat mengakses sistem di server pusat dan mengunggah nilai-nilai peserta didik dan kemudian mengunduh file rapor yang sudah jadi sekaligus mencetaknya. Komputer server dan komputer client mendapatkan akses internet dari MIFI secara nirkabel dengan tambahan alat yaitu USB Wifi. Baik komputer server maupun komputer client dilengkapi dengan printer warna untuk mencetak rapor dari program aplikasi

Kegiatan pelatihan dilakukan bertempat di salah satu ruang kelas sekolah mitra. Selain dihadiri oleh peserta (guru dan siswa), kegiatan pelatihan juga dihadiri oleh pejabat yaitu pengawas sekolah tingkat kecamatan dan ketua Pengurus Ranting Muhammadiyah (PRM) tingkat desa. Kegiatan pelatihan diawali dengan sambutan pembukaan oleh kepala sekolah yang dilanjutkan dengan sambutan oleh pengawas sekolah tingkat kecamatan dan ketua PRM kemudian baru dilanjutkan dengan acara inti pelatihan. Pelatihan dibagi menjadi dua sesi yaitu sesi satu adalah pengelolaan usaha kesehatan gigi dan mulut sekolah (UKGS) sedangkan sesi kedua adalah pelatihan penggunaan aplikasi Android media pembelajaran kesehatan gigi dan mulut.

\section{Pelatihan Pemeliharaan Gigi dan Mulut}

\section{a. Pelatihan Pengelolaan UKGS}

Untuk kegiatan pelatihan pengelolaan UKGS ini, tim pelaksana kegiatan menggunakan metode penjelasan/presentasi yang kemudian dilanjutkan dengan praktek. Kegiatan pelatihan diawali dengan icebreaking oleh tim pelaksana untuk lebih mencairkan suasana sehingga diharapkan membuat suasana lebih menyenangkan sehingga lebih kondusif. Kemudian tim pelaksana memberikan paparan dan penjelasan mengenai materi-materi: (1) jenis-jenis gigi, (2) rongga mulut dan susunan gigi, (3) ciri-ciri gigi dan lidah yang tidak sehat, (4) jenis-jenis dan ciri-ciri penyakit pada gigi dan mulut, (5) manajemen/pengelolaan UKGS, dan (6) cara menggosok gigi dan lidah yang baik dan benar.

Sesi pelatihan pengelolaan UKGS diakhiri dengan praktek bagaimana cara menyikat gigi yang baik dan benar. Pada saat praktek menggosok gigi yang baik dan benar, tim pelaksana mempraktekkaan pada alat peraga gigi pagaimana cara menggosok gigi yang baik dan benar. Kemudian, tim pelaksana meminta perwakilan peserta secara acak untuk mempraktekkan didepan kelas cara meyikat gigi 
yang baik untuk kemudian diberi masukan oleh tim pelaksana apabila belum benar.

\section{b. Pelatihan Penggunaan Aplikasi Android untuk Pembelajaran Kesehatan Gigi dan Mulut}

Pelatihan penggunaan aplikasi dilakukan dengan menggabungkan metode penjelasan (presentasi) dengan praktek langsung. Pertamatama tim pelaksana memberikan pemaparan mengenai program aplikasi dan kebutuhan perangkat agar dapat menggunakan aplikasi dengan baik. Kemudian, peserta dibimbing untuk mempraktekkan langkah demi langkah mulai dari proses instalasi sampai dengan penggunaannya.

\section{c. Proses Instalasi dan Penggunaan Aplikasi}

Untuk dapat menjalankan aplikasi dengan baik, dibutuhkan perangkat smartphone dengan spesifikasi minimal mempunyai memory sebesar 2 giga byte (GB). Proses instalasi diawali dengan peserta membuka smartphone Androidnya kemudian mengkopikan file program aplikasi yang mempunyai ekstensi *.apk dari komputer atau yang dikirimkan melalui aplikasi sosial media kedalam smartphone. Kemudian peserta membuka menu pengaturan pada smartphone Android. Selanjutnya peserta dibimbing untuk memilih menu aplikasi dan notifikasi dan pilih pasang aplikasi yang tidak diketahui. Langkah berikutnya adalah memilih file program aplikasi yang akan diinstalasi yang mempunyai ekstensi *apk yang sudah dikopikan dari komputer atau smarphone lainnya sebelumnya. Peserta kemudian dibimbing untuk mengizinkan untuk menginstalasi program aplikasi dan menunggu proses instalasi sampai selesai. Setelah proses instalasi selesai maka ikon aplikasi pembelajaran kesehatan gigi dan mulut akan muncul pada layar utama smartphone.

Program aplikasi dapat dibuka dengan cara double click pada icon aplikasi pada layar utama smartphone. Setelah program aplikasi terbuka maka akan muncul tampilan utama seperti yang dapat dilihat pada Gambar 4. Pada tampilan utama program aplikasi terdapat beberapa tombol utama yaitu tombol untuk pengaturan aplikasi, tombol untuk keluar aplikasi dan tombol untuk masuk program aplikasi. Tombol pengaturan memungkinkan pengguna untuk mematikan musik latar yang ada pada aplikasi. Tombol keluar aplikasi adalah tombol yang digunakan untuk menutup program aplikasi dan keluar dari program aplikasi. Untuk dapat masuk kedalam program aplikasi, peserta pelatihan dibimbing untuk menekan tombol "Mulai". Setelah tombol "Mulai" ditekan, maka tertampil halaman menu aplikasi utama seperti yang ditampilkan pada Gambar 5. Pada halaman menu aplikasi terdapat tombol kembali yang digunakan oleh peserta untuk kembali ke tampilan sebelumnya. Aplikasi mempunyai dua bagian yaitu media pembelajaran dan game edukasi. Media pembelajaran berisi dua sub menu yaitu jenis-jenis gigi dan ciri-ciri gigi.

Apabila tombol "Jenis-jenis Gigi" atau "Ciriciri Gigi" atau "Game Edukasi" ditekan maka program aplikasi akan menampilkan sub-sub menu yang ada didalamnya lagi. Sub-menu dan bagian-bagian didalamnya pada masing-masing bagian media pembelajaran dan game edukasi selengkapnya dapat dilihat pada peta menu aplikasi yang digambarkan pada Gambar 6 .

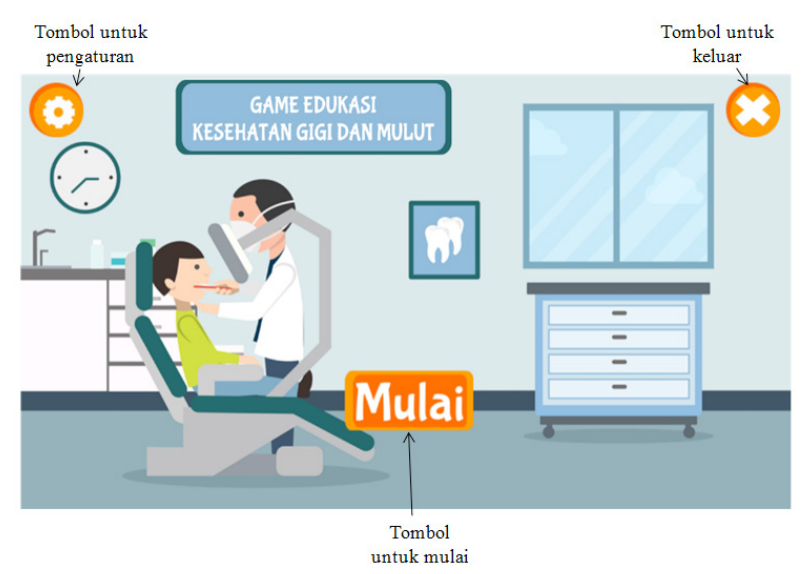

Gambar 4. Tampilan halaman depan program aplikasi kesehatan gigi dan mulut.

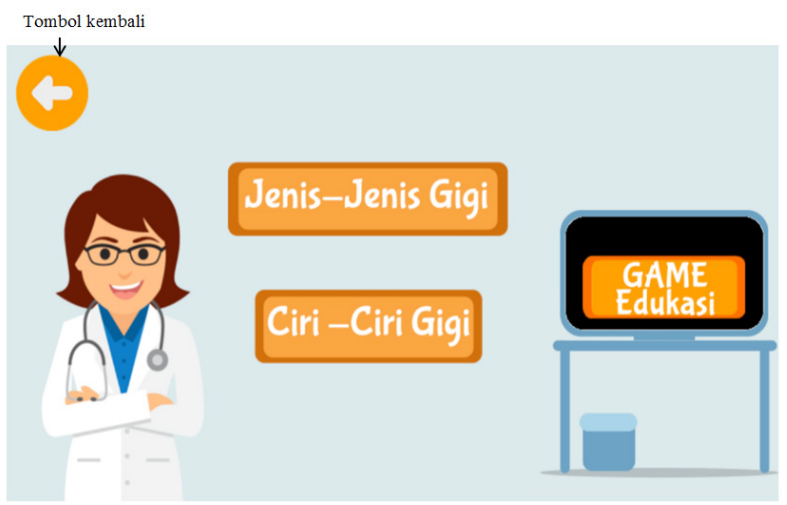

Gambar 5. Tampilan menu aplikasi utama. 


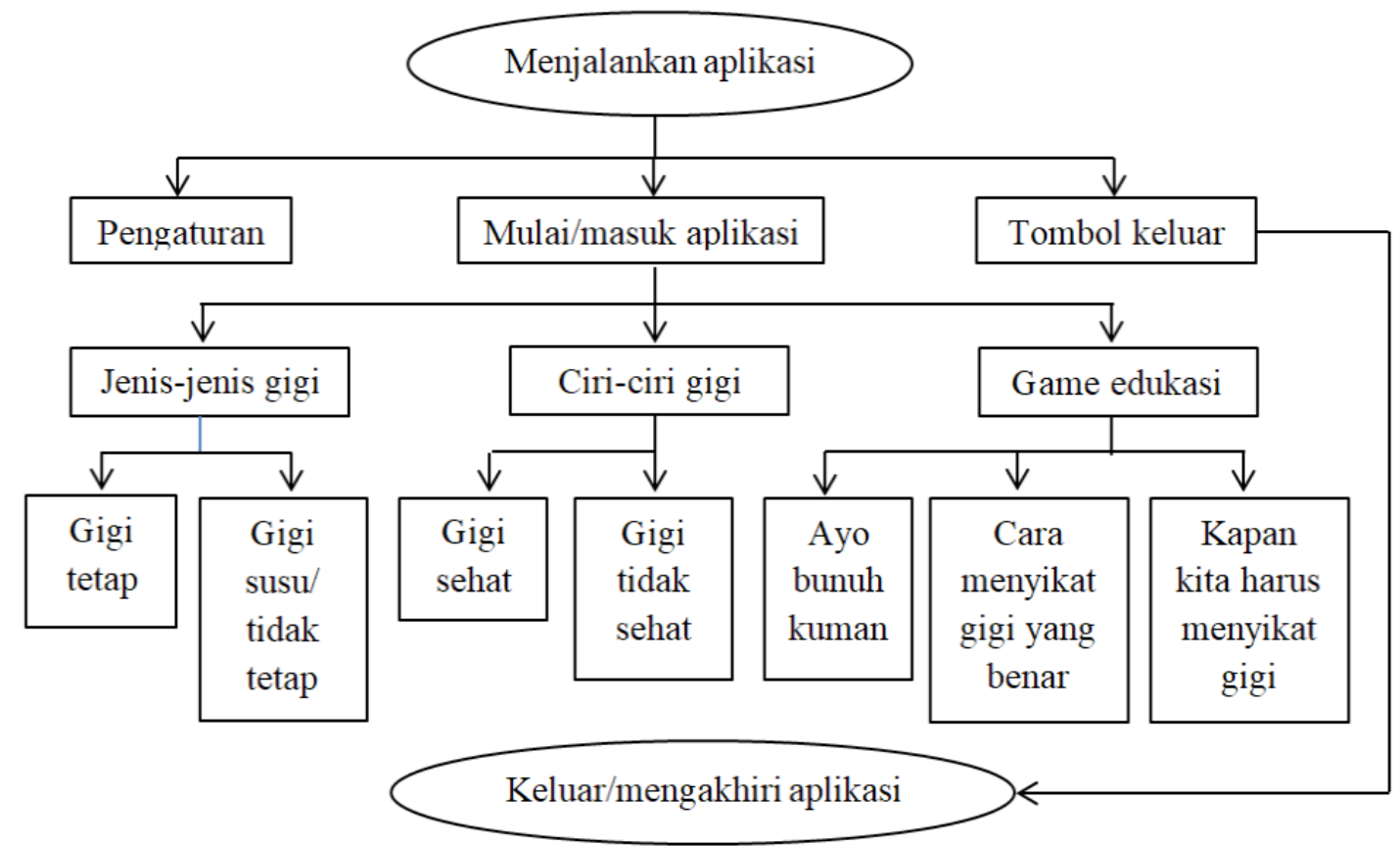

Gambar 6. Peta menu pada program aplikasi.

\section{d. Media pembelajaran jenis-jenis gigi}

Pada menu ini peserta dapat mempelajari jenis-jenis gigi pada manusia yang dibagi menjadi dua kelompok yaitu kelompok gigi tetap dan kelompok gigi susu/tidak tetap. Pada masingmasing kelompok, peserta pelatihan dapat melihat tampilan grafis peta gigi pada geraham atas dan geraham bawah mana yang termasuk gigi tetap dan gigi susu yang dilengkapi dengan musik latar dan suara narasi untuk menyebutkan gigi. Juga ada tampilan animasi gambar kartun orang/dokter gigi yang menunjukkan urutan masing-masing gigi. Peserta dapat menggeser petunjuk posisi gigi dengan cara menekan tombol tanda panah lanjutyang sudah disediakan dalam tampilan tersebut. Apabila peserta akan berpindah materi pembelajaran dari materi gigi tetap ke gigi susu atau sebaliknya maka peserta dapat menekan tombol panah kembali di bagian kiri atas tampilan program aplikasi.

\section{e. Media pembelajaran ciri-ciri gigi}

Pada menu ini, program aplikasi akan menampilkan dua kelompok materi yaitu kelompok materi gigi sehat dan kelompok materi gigi tidak sehat. Pada masing-masing kelompok materi, program aplikasi akan menampilkan rangkuman ciri-ciri gigi sehat maupun tidak sehat disertai dengan tampilan foto contoh, musik latar dan suara narasi. Setelah selesai belajar pada materi ciri-ciri gigi, peserta dapat menekan tombol panah kembali di bagian kiri atas tampilan program aplikasi.

\section{f. Game edukasi}

Untuk dapat mengakses game edukasi, peserta pelatihan dapat melakukannya dengan menekan tombol "game edukasi" pada tampilan menu utama program aplikasi pada Gambar 5. Game edukasi ini merupakan permainan atau game dengan materi pembelajaran gigi dan mulut sehingga tidak hanya untuk memberikan kesenangan atau hiburan kepada peserta namun juga sekaligus belajar atau istilahnya adalah belajar melalui permainan.

Program aplikasi ini menyediakan tiga jenis game yaitu ayo bunuh kuman, cara menyikat gigi yang benar, kapan kita harus menyikat gigi. Masing-masing permainan ditempatkan pada sebuah ruang pada skenario rumah bertingkat dengan susunan yang menantang untuk menguji kecepatan motorik peserta. Masing-masing ruang akan ditutp dengan pintu dengan warna yang berbeda-beda yaitu biru, hitam dan kuning. Pintu-pintu ini hanya dapat dibuka dengan menggunakan kunci dengan warna yang sama.

Tahap permainannya adalah pertamatama peserta harus mengambil kunci untuk masing-masing ruang tempat permainan disimpan dengan cara menggulirkan bola hitam 
dengan cara menyentuhnya pada tampilan layar smartphone. Apabila bola hitam mengenai kunci maka peserta sudah berhasil mendapatkan kunci untuk ruang permainan yang sesuai dengan warnanya dan ruang tempat permainan terbuka secara otomatis. Setelah itu, peserta harus segera menuju ke ruangan permainan dalam waktu yang dibatasi. Rute perjalanan dari lokasi kunci ke ruang permainan dibuat cukup menantang untuk meningkatkan minat dan membangkitkan rasa penasaran peserta. Rute perjalanan meliputi lintasan yang berbentuk tangga maupun bukit/tembok dimana peserta harus mampu menggiring bola masuk ke ruang permainan yang sudah terbuka pintunya. Apabila sampai waktu yang ditentukan peserta tidak mampu mencapai ruang yang sudah terbuka tadi maka pintu akan tertutup kembali dan peserta harus mengambil kunci kembali.

Game edukasi cara menyikat gigi yang benar dan kapan harus menyikat gigi adalah permainan yang berbentuk puzzle. Peserta diminta untuk menata kepingan-kepingan puzzle yang akan membentuk suatu tampilan gambar tentang bagaimana menyikat gigi yang benar dan kapan harus menyikat gigi. Apabila peserta berhasil menyusun puzzle dengan benar maka akan mendapatkan reward/hadiah berupa bintang. Untuk masing-masing permainan disediakan tampilan waktu pada pojok kanan atas yang akan digunakan untuk mengukur lama waktu yang dibutuhkan oleh peserta untuk menyusun puzzle, semakin cepat semakin baik.

Game edukasi yang ketiga adalah permainan menembak kuman. Pada game ini terdapat meriam yang dapat digerakkan oleh peserta pelatihan. Selain itu juga terdapat pasta gigi dan kuman yang berjatuhan dari atas. Pada game ini terdapat tampilan nyawa pada bagian kiri atas tampilan aplikasi. Apabila meriam terkena kuman maka akan mengurangi nyawa sebanyak satu dan apabila meriam terkena pasta gigi yang jatuh maka nyawa akan bertambah satu. Peserta dapat menembakkan meriam dengan sasarannya adalah kuman gigi. Apabila tembakan meriam berhasil mengenai kuman maka peserta akan mendapatkan nilai.

Setelah berhasil mempraktekkan semua game edukasi yang ada, peserta dapat menekan tombol kembali untuk dapat kembali ke menu sebelumnya dan kemudian untuk keluar/ mengakiri penggunaan program aplikasi berbasis Android ini.

\section{g. Evaluasi pelaksanaan pelatihan penggunaan aplikasi media pembelajaran Android}

Untuk mengetahui tingkat keberhasilan kegiatan pelatihan penggunaan aplikasi media pembelajaran kesehatan gigi dan mulut berbasis Android ini maka tim pelaksana melakukan evaluasi kegiatan. Evaluasi kegiatan dilakukan dengan cara meminta peserta untuk mengisi kuesioner setelah kegiatan pelatihan berakhir.

Didalam kuesioner terdapat beberapa pernyataan sebagai berikuti: (P1) aplikasi mempunyai tampilan yang menarik, (P2) aplikasi mudah digunakan, (P3) aplikasi terlalu rumit, (P4) konten aplikasi sudah sesuai dan cukup lengkap untuk belajar kesehatan gigi dan mulut, (P5) aplikasi bermanfaat untuk mendukung belajar kesehatan gigi dan mulut, (P6) aplikasi layak digunakan untuk digunakan belajar kesehatan gigi dan mulut, dan (P7) saya puas dengan sosialiasi ini. Untuk masingmasing pernyataan dalam kuesioner, peserta diminta untuk memberikan jawaban mereka dalam bentuk derajat kesetujuannya yang dikonversikan dalam angka yaitu: sangat setuju (5), setuju (4), tidak setuju (2), dan sangat tidak setuju (1). Untuk masing-masing pernyataan, nilai akhir dihitung dengan menggunakan rumus 1.

$$
P=\frac{\sum_{i=1}^{N} S_{i}}{5 N} \times 100 \%
$$

dengan $P$ adalah nilai persentase untuk masingmasing pernyataan, $i$ adalah indeks peserta pelatihan, $N$ adalah jumlah maksimal peserta pelatihan, dan $S_{i}$ adalah jawaban oleh peserta yang ke-i.

Hasil pengolahan data kuesioner untuk semua pernyataan dari P1-P7 menunjukkan nilai persentase diatas $90 \%$ kecuali untuk pernyataan P3 yaitu pada nilai dibawah 20\% sehingga dapat diambil kesimpulan secara umum bahwa aplikasi yang diimplementasikan pada mitra sudah mempunyai tampilan yang menarik, mudah digunakan, tidak terlalu rumit, kontennya sudah cukup lengkap, dan sudah layak digunakan 
untuk media pembelajaran kesehatan gigi dan mulut. Khusus untuk pernyataan P7: "Saya puas dengan sosialisasi ini" mendapatkan nilai $100 \%$ yang menunjukkan bahwa peserta sangat antusias dengan adanya kegiatan introduksi dan sosialisasi aplikasi media pembelajaran berbasis Android.

\section{Perbandingan Keadaan Sebelum dan Sesudah Pelaksanaan Pengabdian}

Perbandingan keadaan antara sebelum dan sesudah pelaksanaan kegiatan pengabdian dapat dilihat pada Tabel 2. Keadaan ini menunjukkan bahwa kegiatan pengabdian pada masyarakat dapat meningkatkan kualitas pelayanan akademik pada sekolah mitra yaitu sekolah sudah mempunyai infrastruktur komputer guna mendukung implementasi ARD, guru sekolah meningkat pengetahuannya dalam pemeliharaan kesehatan gigi dan mulut serta pengelolaan UKGS, dan yang terakhir sekolah sudah mempunyai aplikasi media pembelajaran gigi dan mulut berbasis Android.

\section{KESIMPULAN}

Dari hasil uraian yang disajikan pada hasil dan pembahasan dapat diambil kesimpulan permasalahan yang dihadapi sekolah mitra yaitu belum dapat diaksesnya e-rapor/ARD sudah berhasil diatasi dengan pengaplikasian infrastruktur komputer dengan server dan lokal terhubung dengan server pusat dengan berbasis komunikasi data seluler GSM dengan alat MIFI. Aplikasi infrastruktur komputer dalam kegiatan ini meningkatkan kualitas pelayanan akademik pada sekolah mitra yaitu dengan diterapkannya aplikasi rapor digital. Hasil analisis kuesioner menunjukkan $90 \%$ peserta menilai program aplikasi Android media pembelajaran kesehatan gigi dan mulut mempunyai tampilan yang menarik, mudah digunakan, mempunyai konten yang mencukupi dan sudah layak digunakan untuk sarana pembelajaran. Selain itu 100\% peserta merasa puas dengan pelaksanaan kegiatan. Hasil ini menunjukkan bahwa kegiatan pelatihan pemeliharaan kesehatan gigi dan mulut yang menerapkan aplikasi media pembelajaran berbasis Android mampu meningkatkan pengetahuan peserta dan peserta sangat antusias dengan penggunaan media pembelajaran dibandingkan dengan hanya belajar menggunakan media cetak saja.

Saran untuk kegiatan lebih lanjut adalah diterapkannya sistem komputer untuk pembayaran sekolah dan penerimaan peserta didik baru.

\section{PERSANTUNAN}

Tim pelaksana pengabdian mengucapkan terimakasih kepada semua pihakyangmembantu atas terlaksananya kegiatan ini diantaranya yaitu Direktorat Riset dan Pengabdian pada Masyarakat (DRPM) Kemenristekdikti yang sudah mendukung kegiatan dengan memberikan dana hibah melalui skema Program Kemitraan Masyarakat (PKM), Lembaga Penenelitian dan Pengabdian kepada Masyarakat Universitas Muhammadiyah Surakarta (LPPM UMS) yang sudah mendampingi pelaksanaan dan MIM Potronayan 1 sebagai mitra.

Tabel 2. Perbandingan kondisi sebelum dan sesudah pelaksanaan pengabdian

\section{Sebelum Kegiatan Pengabdian}

Sekolah belum mempunyai sarana komputer yang mencukupi untuk pengolahan rapor berbasis komputer.

Pengetahuan guru dan siswa dalam pemeliharaan kesehatan gigi dan mulut masih terbatas

Sekolah belum mempunyai media pembelajaran kesehatan gigi dan mulut berbasis Android dengan fitur game edukasi.

\section{Sesudah Kegiatan Pengabdian}

Sekolah sudah mempunyai sarana komputer yang mencukupi untuk pengolahan rapor berbasis komputer.

Pengetahuan guru dan siswa dalam pemeliharaan kesehatan gigi dan mulut sudah meningkat setelah mengikuti pelatihans

Sekolah sudah mempunyai media pembelajaran kesehatan gigi dan mulut berbasis Android dengan fitur game edukasi. 


\section{DAFTAR PUSTAKA}

Fauzi, Fauzi; Harly, Gevin Sepria; Hanrais, HS. 2012. Analisis Penerapan Teknologi Jaringan LTE 4G di Indonesia. Majalah Ilmiah UNIKOM, 10(2), 281 - 289.

Kemenkes Republik Indonesia. 2017. Usaha Kesehatan Sekolah (UKS) menjadi Transformasi dalam Upaya Kesehatan di Lingkungan Sekolah. http://sehatnegeriku.kemkes.go.id/baca/ rilis-media/20170227/5419937/unit-kesehatan-sekolah-uks-menjadi-transformasi-upayakesehatan-lingkungan-sekolah/ (diakses tanggal 21 September 2018).

Santoso, B.W., Iswahyudi, C., \& Triyono, J. 2015. Teknologi 4G Pada Jaringan GSM Untuk Kebutuhan Mobile Internet di Kota Yogyakarta. Jurnal JARKOM, 2(2), 32-43.

Supriyono, H.; Rahmadzani, R.F., Adhatoro, M.S., \& Susilo, A.K. (2016). Rancang Bangun Media Pembelajaran Dan Game Edukatif Pengenalan Aksara Jawa "Pandawa". Prosiding The 4th University Research Colloquium (URECOL) 2016, 1-12.

Supriyono, H., Sudarmilah, E., Fadlilah, U., Rahayu, E. T., \& Purwohartono, A. 2015. Rancang Bangun Media Pembelajaran Bahasa Dan Huruf Jawa Berbasis Adobe Flash Cs6, Prosiding The 2nd University Research Coloquium 2015 ISSN 2407-9189, pp. 1-9.

Supriyono, H., Sutopo, A., Saputro, R. D., Senoadi, I., Firdaus, G. N. 2016. Implementasi Perancangan Jaringan Komputer di SMP Muhammadiyah 1 Kartasura. Seminar Nasional Ilmu Komputer (SNIK) 2016, Oktober 2016, 1-6.

Supriyono,H., Widjaya, J.A., \& Supardi, A. 2013. Penerapan Jaringan Virtual Private Network Untuk Keamanan Komunikasi Data Bagi PT. Mega Tirta Alami. WARTA, 16(2), 88 - 101.

Tanenbaum, Andrew S. 2003. Computer Networks Fourth Edition, Prentice Hall, ISBN: 0-13-066102-3 